\title{
A Comparative Study of Environmental Performance Indicators of Asian Eco-Cities
}

\author{
ZHONGJIE LIN \\ University of North Carolina at Charlotte
}

\begin{abstract}
Although the concept "Eco-city" has been discussed and promoted for decades, it was in the past several years that we started to see an increasing number of large-scale projects translating it into practice. It refers to an ecologically healthy city that enables residents to live a high-quality life with minimal impact on environment, a goal accepted across many cultures. Eco-city is now a global phenomenon, yet Asia shows particularly notable development with strong governmental intervention, and witnessed ambitious, systematic national initiatives to build exemplary eco-cities. In Japan, the central government launched the "Eco-Town Project" initiative in 1997, then turned it into a more comprehensive "Eco-Model Cities" scheme announced at the 2008 G8 Summit in Hokkaido. So far twenty-three cities have been designated as Eco-Model Cities, ranging from large cities like Yokohama to small towns like Minamata. Financial incentives are provided to undertake major urban restructuring, low-carbon developments, and sustainable industries. The objective is to develop models of ecological urbanism that would subsequently influence the rest of the country.
\end{abstract}

Arguably the most ambitious eco-city program, at least in terms of the number of initiatives and scale of projects, is currently taking place in China, where more than 100 new eco-towns are under development and some 259 existing cities have declared their intention to become an "eco-city" or "low-carbon city" (China Urban Sciences Research Council, 2011). The central government has aspired to lead cities onto the path of sustainable urbanization by creating a number of high-profiled eco-city demo projects, such as Dongtan Ecocity (with technical support from the United Kingdom) in 2004 and Tianjin Eco-city (a joint venture with Singapore) in 2007. Eco-cities are promoted as innovative urban policy strategies and practices under the overarching paradigm of "ecological modernization," which seeks to de-couple economic growth from environmental degradation by incentivizing low-carbon, low-waste economic development.

This paper studies the planning and development of model eco-cities in Japan and China, using a comparative method to examine their policies and programs, design and development strategies, and technological specifics. It aims to extract some of the characteristics of contemporary Asian urbanism and map its path toward a low-carbon society. The comparison will mainly focus on the data of two model eco-city projects, Tianjin Eco-city in China and Kitakyushu in Japan, and address a few key issues of eco-cities in order to enhance the understanding of Japan's and China's policies and practices including their common, and contrasting, approaches to urban sustainability, the relationship between the building of an eco-city and local economic and cultural development, the roles played by the governments and the private sector in this effort, and the influence of these model eco-projects on the rest of the country.

\section{THE RISE OF ECO-CITY MOVEMENTS IN JAPAN AND CHINA}

Coined by Richard Register in Ecocity Berkeley: Building Cities for a Healthy Future (1987), the concept of "eco-city" originated from the fundamental objective of sustainability and the application of ecological principles on urban planning, design and management. The United Nations Earth Summit in Rio de Janeiro, 1992, and the resulted sustainable development programme Agenda 21 formed the institutional background to support development of eco-city. Until the end of the twentieth century, however, there were still few practical examples of eco-city practices, and most of them were located in Europe and remained at modest scale, such as Schwabach, the historic town in Germany and BedZED, the carbon-neutral community in England. The beginning of the 21st century saw urban population surpassing rural population for the first time in human history. Asia emerged at the forefront of eco-city development because the region as a whole are rapidly urbanized, with a number of projects of international influence like Masdar in the United Arab Emirates and the Delhi-Mumbai Industrial Corridor supported with input from Japan (Joss, 2011).

Japan and China distinguish themselves among other countries in eco-city development, characterized by strong governmental intervention in this enterprise, and resulting in ambitious, systematic national initiatives to build exemplary eco-cities. In Japan, national and local governments are spearheading the drive to bring together industry clusters to be more sustainable, which focus on energy conservation, material development and integrated waste management. The eco-city concept in Japan was formalized in 1997 with the passing of legislation that included a subsidy system for "EcoTown" projects. The Ministry of Economy, Transportation and Infrastructure (METI) and the Ministry of the Environment (MoE) sponsor the program. The Eco-Town program focuses on making decisions at the local level and having industry and citizens work with the local government to make changes and to assist companies in declining industries 
such as steel and cement through the Zero-Emission concept (Global Environment Centre Foundation, 2005; Berkel, 2009). Kawasaki, lida, Kani, and Kitakyushu were among the cities approved as Eco-Towns in the first year, and since then twenty-six cities have been included in this program. In February 2008, the Japanese government established a Cabinet-level Panel on Low-Carbon Society to study solutions to deal with global warming and a wide range of related issues, and to shift the country to a low-carbon society. One of the decisions made by the panel was the creation of "Eco-Model Cities." The panel chose model cities in order to promote drastic reductions of greenhouse gas emissions and encourage local communities to promote integrated efforts that incorporate existing knowledge and information into social and economic systems and make good use of local characteristics. Consequently, six cities - Yokohama, Kitakyushu, Toyoma, Obihiro, Shimokawa, and Minamata - were chosen from 82 total applications as the first group of Model-Eco Cities, which was announced at the G8 Summit at Hokkaido in 2008. Both the Eco-Town program and the Model Eco-City initiative address particular issues of Japanese society such as shortage of natural resources and the aging population. The eco-city concept is also seen in Japan as an effective way to revitalize previously environmentally degraded cities, direct national government funding to the most effective areas, and deal with climate change in the face of the reduction of nuclear power as a result of the 2011 Fukushima disaster. The rise of trans-boundary environmental problems has also encouraged Japanese governments to work with their Asian neighbors, to share their know-how and promote low-carbon societies in the region.

China, on the other hand, is experiencing rapid and large-scale urbanization, and its urban environmental is facing unprecedented challenges under the dramatic growth. The government has recognized the urgency of coping with these challenges and incorporated agendas of developing sustainable cities since the nation's 11th Five-Year Plan, which announced a Renewable Energy Medium-Long Term Plan (Ghiglione, 2015). The 17th National Congress of Chinese Communist Party (CPC) in 2007 put forward the low-carbon eco-city model as an important part of the overarching agenda of "eco-culture" calling for the building of "a harmonious world characterized by sustained peace and common prosperity" (State Council of Information of China, 2005). More recently, "urbanization" was highlighted in the 18th National Congress of Chinese Communist Party, particularly advocated by Premier Keqiang Li, as the keyword of Chinese economic restructuring in the coming decade. $\mathrm{Li}$ called for leading the country's mass urbanization toward a sustainable path to create new venues for jobs, consumptions, and investments, to balance mega-cities with small towns, to correct economic disequilibrium between coastal and inland regions, and to improve energy efficiency and air quality. All these directives have encouraged local governments to pursue eco-city developments. By 2014, more than 230 cities have responded with initiatives to create eco-cities or lowcarbon cities following the standards set by the Ministry of Environmental Protection (MEP) and the Ministry of Housing and Urban-Rural Development (MoHURD) (Ghiglione, 2015).

A comparison of the eco-city movements in Japan and China reveals both common approaches characteristic of eco-city development in Asia as well as fundamental differences in their respective policies and strategies toward urban sustainability. They emphasize different aspects of eco-city, and involve the governments and the private sector for different roles in this effort, which lead to different model of eco-city. One of fundamental distinctions involves the models of retrofit versus new town development. Retrofitting existing cities appears to be the primary way of building low-carbon cities in Japan. It stands in contrast to China's approach of planning and building numerous eco-cities from scratch due to its explosive urbanization. Another issue to compare is the different approaches to ecocity between top-down and bottom-up. Both governments in Japan and China took the lead and played an important role in eco-city development, and the projects were carried through public-private collaboration. However, the roles that the national government, municipal governments, and private organizations play are different in Japan and China, and the public-private collaboration is implemented in various ways. In most cases, Japanese eco-cities followed a bottom up approach where it takes a good deal of effort on behalf of a city or town to apply for one of the national programs, and the projects move forward through cooperation between government, citizens and other stakeholders. Most of Chinese eco-cities, on the other hand, are top-down initiatives by the national or local governments that prioritize political influence and economic development, and carried out by developers associated to the government. Comparisons of these different models of retrofit versus new town and top-down versus bottom-up through the case studies of Kitakyushu and Tianjin Eco-city brings up more details of the policies, designs, and implementation of eco-city in Japan and China.

\section{KITAKYUSHU AND TIANJIN ECO-CITY}

Kitakyushu and Tianjin Eco-city are regarded as the "models" of eco-city development in Japan and China respectively. Both have a comprehensive ecological agenda and have established detailed environmental performance indicator system. Both receive substantial governmental support and enjoy extensive international exposure - Kitakyushu was among the first to be included in the Eco-Town program as well as in the Eco-Model City Initiative, and Tianjin Eco-city originated from the intergovernmental collaboration between China and Singapore. Both have developed incrementally for a number of years and seen the result of ecological planning. Tracking the transformation under the eco-city agenda, analyzing their spatial components, and comparing their indicator systems would provide insights into the different paths of sustainable urbanism in the two countries. 


\section{SMART SPOT}

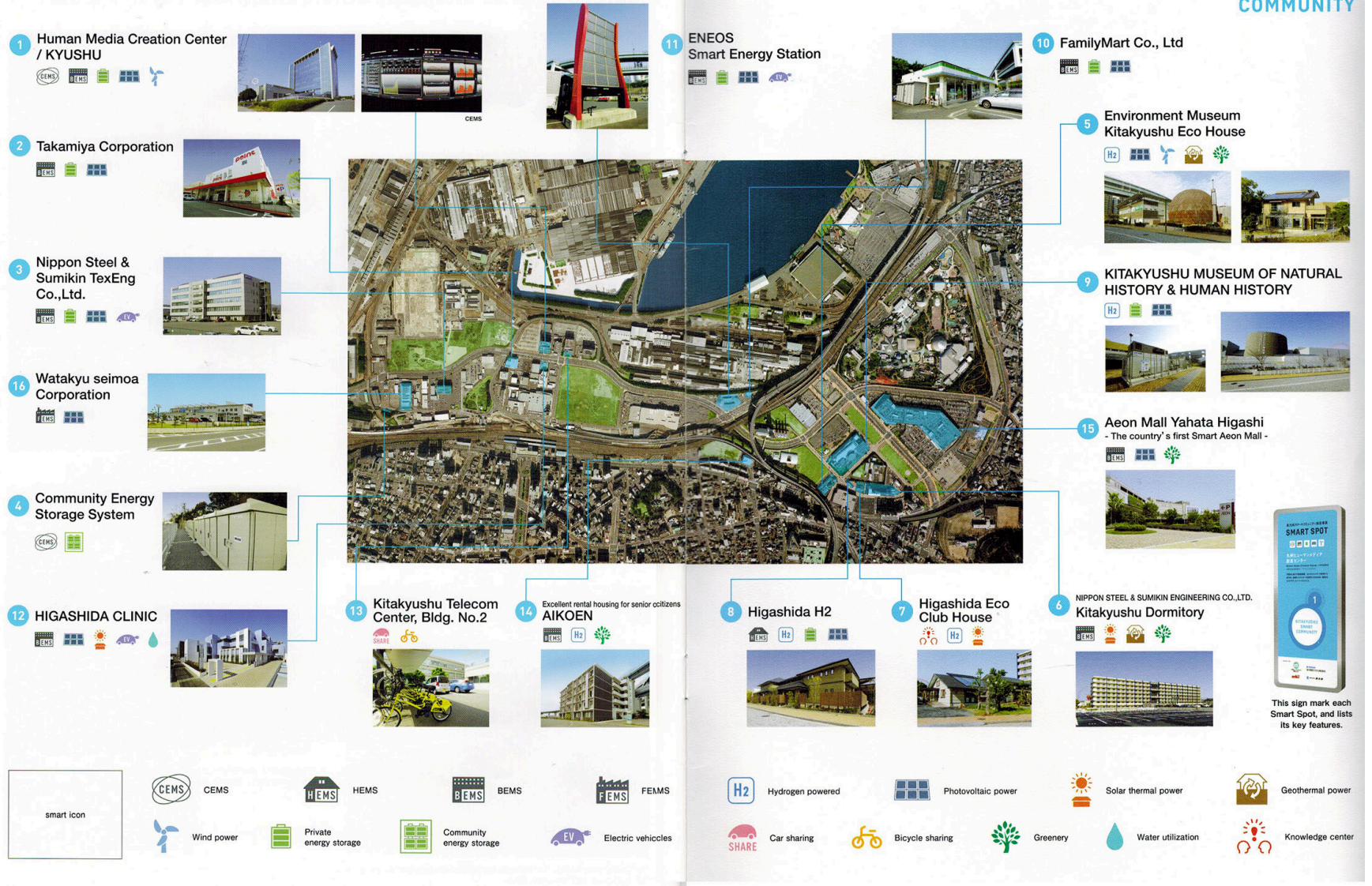

Fig 1:Higashida Smart Community project in Kitakyushu.

Kitakyushu is a city of approximately a million residents located in Fukuoka Prefecture in Kyushu. It rose as one of the early industrial bases of Japan in the early 20th century, and continued to develop developed through the post-WWII period. The growing manufacturing power, however, also impacted the city from the other side, making it one of the heavily polluted placed in the country. In the 1960s, the Women's Association in Kitakyushu launched the anti-pollution campaign, which pushed the local government to enact a Pollution Control Ordinance and the private sectors to sign on a series of pollution prevention agreements. The grass-root organizations continued to play an important role in the city's drive for sustainability, particularly after the emergence of Local Agenda 21 in 1996 (SCl, 2012). Despite all the top-down policies and incentives that the city has been readily received, Kitakyushu's pursuit of urban sustainability remains pretty much bottom-up practices and involved different walks of the city.

On the other hand, the Sino-Singapore Tianjin Eco-City (SSTEC), or simply Tianjin Eco-city, is a brand new town built from scratch. Although the eco-city is within the municipality of Tianjin, the third largest city in China, it is located in the seafront area of Binhai about 40 kilometers away from the center city. It was inaugurated in 2007 under the inter-governmental partnership between China and Singapore, which split the holding of this joint venture. The eco-city occupies a total area of 34.2 square kilometers and will be home to 350,000 residents when completely built in 2020. It aspires to be a "thriving city, which is socially harmonious, environmentally friendly and resource-efficient - a model for sustainable development" (Tianjin Eco-City website). The choice of the site with its majority being saline-alkali land and wasteland indicates the governments' awareness of ecological challenges and shrinking land resources and determination to tackle these issues. The parties creating this project learned from the lessons of Dongtan, and were able to push forward the development with a comprehensive planning framework, higher density, yet less ambitious environmental agenda. By 2014, a $3 \mathrm{~km} 2$ pilot area has been completed with approximately 10,000 residents living there. In addition, about 1,000 businesses have registered in the Eco-city, attracted by some financial incentives. These are not impressive number as they are still far from the targets, nevertheless indicating the consistent progress of the project.

Planned by the government and developed primarily by state-owned companies along with their Singaporean counterparts, Tianjin Eco-city followed a top-down approach although the joint venture is operated like a corporation. 

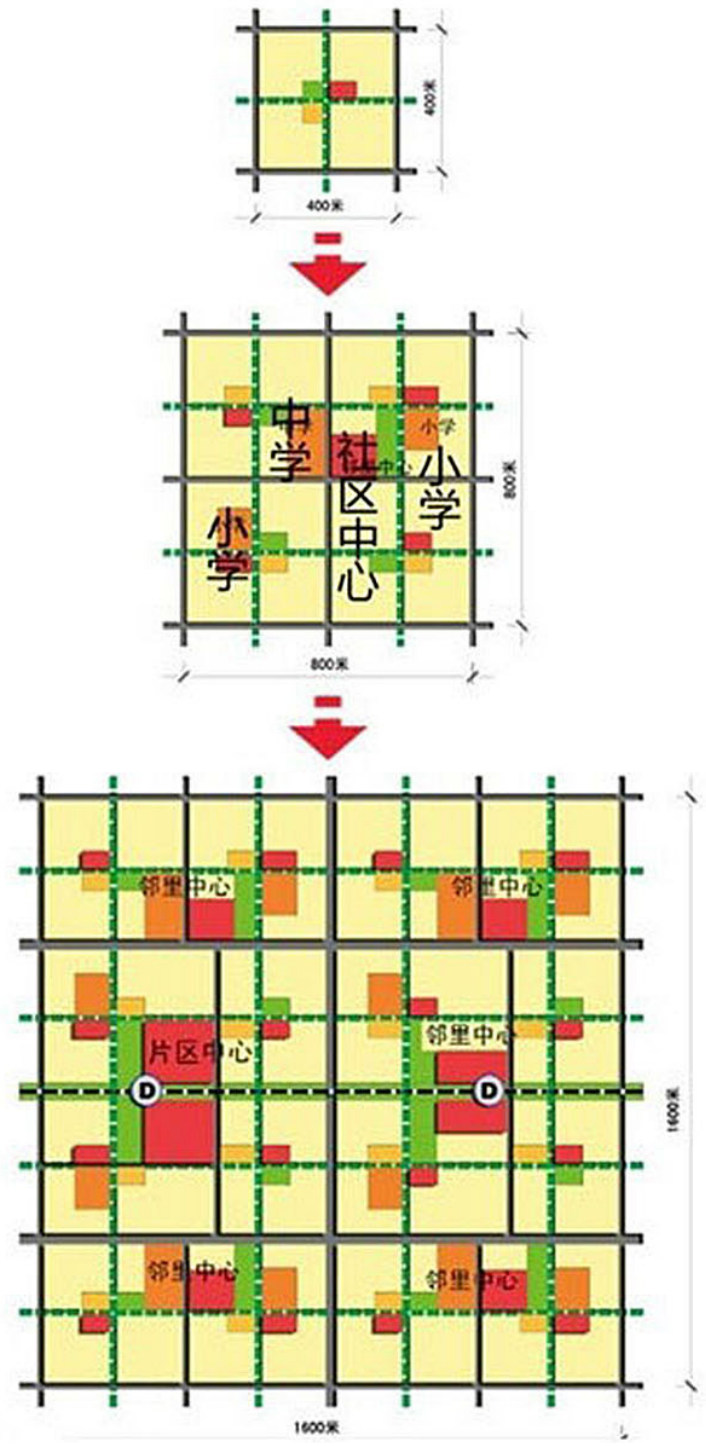

Fig 2: Tianjin Eco-City Master Plan and Concept of Neighborhood Unit.

The primary economic driver of such project is not incentives for environmental improvement, but rather financial return from land development. Most eco-city projects in China follow this path. They looked to Tianjin as a model for standards and implementation of planning and building an eco-city. They framed their indicators based on Tianjin's EPI system, and many sought international partners for importation of know-how and, more importantly, added brand value, such as Sino-Sweden Low-Carbon Eco-City and Caofeidian EcoCity (also with Sweden).

\section{ENVIRONMENTAL PERFORMANCE INDICATORS}

The Environmental Performance Indicators (EPIs) is an essential tool for planning and evaluating the eco-city. An EPI system defines a series of threshold or target indexes of social or environmental quality that the city intends to reach within a certain timeframe as the goals of sustainability. The approach to selecting indicators generally falls into two

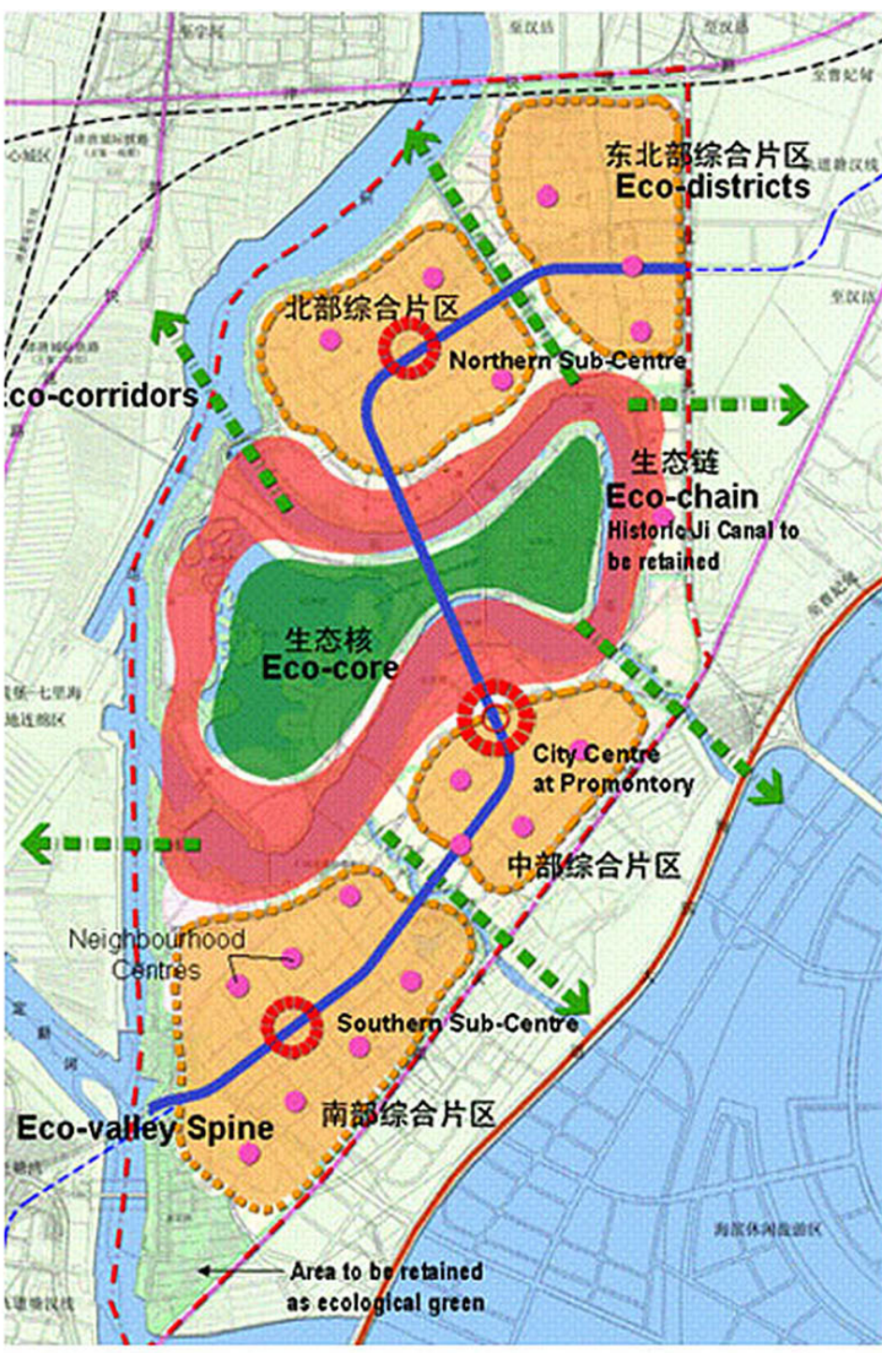

general categories, top-down or bottom-up. The top-down approach means policy makers define the goals and accompanying indicators, and the data collected is usually highly technical and requires experts to interpret. The bottom-up approach is community-based and involves extensive consultation with stakeholders to select appropriate indicators $(\mathrm{SCl}$, 2012). Kitakyushu and Tianjin Eco-city represent two different approaches to controlling and measuring the development of eco-city. As a brand new city and a project controlled by the government, Tianjin followed a top-down method with a set of target indicators laid out by planning and technological specialists in Singapore and China. Kitakyushu's model is characterized by a model influenced both the top-down and bottom-up forces, and tends to more community-based and more flexible in responding to changing conditions.

Kitakyushu's indicators system is based on the so-called DPSIR (Driving forces, Pressures, State of the Environment, Impacts, Response) System. DPSIR is a framework for organizing information about the state of environment. It is a framework 


\begin{tabular}{|c|c|c|c|}
\hline No. & KPI Area and Detail & Indicative Value & Time Frame \\
\hline \multicolumn{4}{|c|}{ I. Environment } \\
\hline 1 & Carbon emission & $\begin{array}{l}11.8 \text { million ton } \mathrm{CO}_{2}(25 \% \text { cut based on } \\
15.6 \text { million in } 2005)\end{array}$ & 2025 \\
\hline 2 & Generation of renewable energy & $730,000 \mathrm{KW}$ (up from $40,000 \mathrm{KW}$ in 2010 ) & 2025 \\
\hline 3 & $\begin{array}{l}\text { Reduction of carbon emission with green } \\
\text { Transportation system }\end{array}$ & $\begin{array}{l}\text { 2,362 ton } \mathrm{CO}_{2}(29 \% \text { cut based on } 3,315 \text { ton } \\
\text { in 2011) }\end{array}$ & 2025 \\
\hline 4 & $\begin{array}{l}\text { No. of strategic international cooperation } \\
\text { projects }\end{array}$ & 10 (up from 3 in 2010) & 2025 \\
\hline 5 & $\begin{array}{l}\text { No. of international environmental trainees } \\
\text { accepted }\end{array}$ & $\begin{array}{l}3,000 \text { in 2021-2025 (up from 2,077 in } \\
2006-2010 \text { ) }\end{array}$ & 2025 \\
\hline 6 & Bio-diversity & Zero loss of species in protected area & 2025 \\
\hline 7 & No. of people participating in eco-tours & 1 million (up from 100,000 in 2010 ) & 2025 \\
\hline 8 & Amount of lithium-ion battery recycled & $\begin{array}{l}25,000 \text { ton ( } 25 \% \text { of Japan, up from zero in } \\
2010 \text { ) }\end{array}$ & 2025 \\
\hline 9 & Solar panel system recycled & 80MW (up from zero in 2010) & 2020 \\
\hline 10 & $\begin{array}{l}\text { Household waste generation and recycling } \\
\text { rate }\end{array}$ & $\begin{array}{l}450 \mathrm{~g} / \text { household (down from } 506 \mathrm{~g} \text { in } 2009 \text { ), } \\
40 \% \text { recycled (up from } 30.4 \% \text { in } 2009 \text { ) }\end{array}$ & 2025 \\
\hline \multicolumn{4}{|c|}{ II. Responses to Aging Society } \\
\hline 11 & $\begin{array}{l}\text { Citizens who feel the efforts of health promo- } \\
\text { tion have been enhanced }\end{array}$ & $30 \%$ (up from $26.7 \%$ in 2010 ) & 2025 \\
\hline 12 & $\begin{array}{l}\text { Citizens who feel the efforts of regional medi- } \\
\text { cal (home care, etc.) have been enhanced }\end{array}$ & $20 \%$ (up from $15.9 \%$ in 2010 ) & 2025 \\
\hline 13 & $\begin{array}{l}\text { Proportion of elderly people feeling their own } \\
\text { health as "good" }\end{array}$ & $50 \%$ (up from $38 \%$ in 2010 ) & 2025 \\
\hline 14 & Employment of elderly people & $25 \%$ (up from $20 \%$ in 2010 ) & 2025 \\
\hline 15 & $\begin{array}{l}\text { Citizen feeling the increase of a network of } \\
\text { mutual support }\end{array}$ & $25 \%$ (up from $20 \%$ in 2010 ) & 2025 \\
\hline 16 & $\begin{array}{l}\text { No. of schools supported by the business } \\
\text { community }\end{array}$ & $\begin{array}{l}\text { All elementary and middle schools (up } \\
\text { from zero in 2011) }\end{array}$ & 2025 \\
\hline 17 & $\begin{array}{l}\text { Proportion of parents feeling support by peo- } \\
\text { ple in the region }\end{array}$ & $70 \%$ (up from $52.2 \%$ in 2010 ) & 2025 \\
\hline \multicolumn{4}{|c|}{ III. Others } \\
\hline 18 & $\begin{array}{l}\text { Support of reconstruction of Great East Japan } \\
\text { Earthquake disaster area using the outcome of } \\
\text { Kitakyushu smart community }\end{array}$ & Consultation is being conducted & immediate \\
\hline 19 & Total floor area of the data center facility & $50,000 \mathrm{~m}^{2}$ (up from $15,000 \mathrm{~m}^{2}$ in 2011) & 2025 \\
\hline 21 & $\begin{array}{l}\text { No. of contracts of international business } \\
\text { projects at Asian Low-Carbon Center of Kita- } \\
\text { kyushu }\end{array}$ & A total of 100 by 2025 (only 1 in 2010) & 2025 \\
\hline 22 & $\begin{array}{l}\text { Technology and know-how related to water } \\
\text { supply and sewage to be exported abroad }\end{array}$ & $\begin{array}{l}6 \% \text { share of the projected } 31 \text { trillion yen } \\
\text { business of water treatment }\end{array}$ & 2025 \\
\hline
\end{tabular}


adopted by the European Environment Agency to assess and manage environmental problems by describing the interactions between society and the environment (SCl, 2012). The framework is composed of the following components:

- Driving forces of environmental change (e.g. industrial production)

- Pressures on the environment (e.g. discharges of waste water)

- State of the environment (e.g. water quality in rivers and lakes)

- Impacts on population, economy, ecosystems (e.g. water unsuitable for drinking)

- Response of the society (e.g. watershed protection)

Some limitations have been identified from past practices of the DPSIR system. For example, the system does not capture the complexity and dynamics of causes and effects of the problem. Therefore, Kitakyushu city has revised the DPSIR into a more community-driven system by adding new elements that reflect the changes in the environmental systems and making it more relevant for the local conditions of Kitakyushu itself as well as the Asian cities that were included in the Kitakyushu Initiative. The result is a set of indicators reflected in the table.

These Indicators were incorporated into the Kitakyushu Green Frontier Plan. Among other goals is a clear target of $50 \%$ CO2 reduction by 2050 compared to the level in 2005, expecting $40 \%$ economic growth in the same period. In addition, the plan also calls for the reduction of $\mathrm{CO} 2$ in the entire Asian Region equivalent to $150 \%$ of Kitakyushu's own emission. The mid-term goal, aiming for 2030, is to reduce the city's carbon emission by 30\% based on the figure in 2005.

Compared to Kitakyushu's model, Tianjin Eco-city's Key Performance Indicators System is more straightforward. This set of KPIs was developed in April 2008 based on the current Chinese national standards and best practices in Singapore. The framework includes 22 quantitative indicators and 4 qualitative indicators. The qualitative indicators appear to be general expectation without operational guidelines such as "maintain a safe and healthy ecology through green consumption and low-carbon operations," while the quantitative ones contain concrete criteria. The quantitative KPIs are grouped into four categories: natural environment, man-made environment, life style, and economy. A number of them represent standards that should be followed from the beginning, some other are expected to realize by 2013, and the rest are set as goals for 2020.Within these KPIs are some standards that represent notable improvement from existing practice, such as preserving wetland, making tap water potable, and demanding all constructions to meet China's Green Building standards. It is also commendable that the eco-city set a concrete carbon density of 150 ton carbon emission per million dollar GDP, and a goal of $90 \%$ green transportation. There are, however, some mediocre numbers. For instance, the renewable energy would account for only 20 percent of the total energy consumption by 2020, compared to China's national plan that requires 15 percent for renewable energy by 2015 . Another KPI call for $20 \%$ of residential development to be subsidized affordable housing, but the number of affordable housing units in Tianjin has been around $50 \%$ of the total new housings since 2011 (Sina News, 2011).

It is neither simple nor very meaningful to compare the individual indicative values of the two cities' indicators system due to their different stages of economic and social development and the different emphases of eco-city agendas. However, it is illuminative to compare the set of data they chosen to include in their respective evaluation system as they indicate their understanding of the eco-city from their respective social contexts. Kitakyushu's system emphasizes reduction of carbon emission and economy of recyclability. Not only is there a firm target of carbon emission for the city in general, each district and many manufacturers have set a mission of carbon emission (Kitakyushu Green Frontier Plan, 2011). In addition, a subset of the indicators is dedicated to the goals of dealing with issues related to the aging society, which is not only a challenge to Kitakyushu, but one facing Japan in general. The populations in many Japanese cities, including other eco-model cities like Kobe, are declining, with young people moving to the country's few mega-cities (Tokyo and Osaka) for better job opportunities and the elderly left without sufficient care. A major objective of the eco-cities in Japan is to strike a balance between creating dynamic economy, through the development of recycling industries among other strategies, and enhancing social sustainability through redistribution of resources. The fact that the evaluation of social sustainability is based on the survey of degrees of satisfaction among residents also demonstrates that bottom-up force plays an important part in shaping the eco-city agenda.

In contrast, the indicators and means of evaluation characteristic of Tianjin Eco-city's KPI system appears to be more objective and technical, indicating characteristics of a topdown approach. As a brand new city, SSTEC focuses on attracting population and businesses through promoting a higher standard of living environment and unique opportunities. Even though urban population in China is growing dramatically, SSTEC is still facing fierce competition with many other new cities across the nations as well as those established urban centers. Economy assumes a high priority in the eco-city development as the administration shrewdly chose the indicators that could help most in enhancing the ecocity's competitive advantage without committing to some high-expense sustainable items. Some scholars also noted that the real estate sector has a lot of say in the direction of 


\begin{tabular}{|c|c|c|c|}
\hline No. & KPI Area and Detail & Indicative Value & Time Frame \\
\hline \multicolumn{4}{|c|}{ I. Natural Environment } \\
\hline 1 & $\begin{array}{l}\text { Ambient air quality (days meeting National Am- } \\
\text { bient Air Quality II Standard) }\end{array}$ & $>310 / \mathrm{Y}$ & Immediate \\
\hline 2 & Quality of water bodies & Grade IV of China's national standards & 2020 \\
\hline 3 & Quality of Water from Taps & Potable & Immediate \\
\hline 4 & Noise Pollution Levels & Satisfy the stipulated standards & Immediate \\
\hline 5 & Carbon Emission Per Unit GDP & $<150$ ton $/ \$ 1$ million & Immediate \\
\hline 6 & Net Loss of Natural Wetlands & 0 & Immediate \\
\hline \multicolumn{4}{|c|}{ II. Man-made Environment } \\
\hline 7 & Proportion of Green Buildings & $100 \%$ & Immediate \\
\hline 8 & Native Vegetation Index & $70 \%$ & Immediate \\
\hline 9 & Per Capita Public Green Space & $>12 \mathrm{~m}^{2} /$ person & Immediate \\
\hline \multicolumn{4}{|c|}{ III. Life style } \\
\hline 10 & Per Capita Daily Water Consumption & $<120$ L/day & 2013 \\
\hline 11 & Per Capita Daily Domestic Waste Generation & $<0.8 \mathrm{~kg}$ & 2013 \\
\hline 12 & Proportion of Green Trips & $90 \%$ & 2020 \\
\hline 13 & Overall Recycling Rate & $60 \%$ & 2013 \\
\hline 14 & Access to Free Recreational and Sports Amenities & $<500$ meter & 2013 \\
\hline 15 & Treatment of hazardous and domestic waste & $100 \%$ & Immediate \\
\hline 16 & Accessibility & $100 \%$ barrier-free access & Immediate \\
\hline 17 & Services Network Coverage & $100 \%$ & 2013 \\
\hline 18 & Proportion of Affordable Public Housing & $>20 \%$ & 2013 \\
\hline \multicolumn{4}{|c|}{ IV. Developing a Dynamic and Efficient Economy } \\
\hline 19 & Usage of Renewable Energy & $>20 \%$ & 2020 \\
\hline 20 & Usage of Water from Non-Traditional Sources & $>50 \%$ & 2020 \\
\hline 21 & $\begin{array}{l}\text { Proportion of R\&D Scientists and Engineers in } \\
\text { the Eco-city Workforce }\end{array}$ & $>50 / 10,000$ workforce & 2020 \\
\hline 22 & $\begin{array}{l}\text { Employment-Housing Equilibrium Index (resi- } \\
\text { dents employed in the Eco-city) }\end{array}$ & $>50 \%$ & 2013 \\
\hline
\end{tabular}

Table 2: KPIs of Tianjin Eco-City. Source: http://www.tianjinecocity.gov.sg

eco-city development. Developers view the concept of ecocity as a selling point and associate them with such values as "luxury" (Springer, 2012). Social equality is marginal in SSTEC's agenda, and it is not surprising the affordable housing accounts for much lower percentage than the average level in the city of Tianjin.

\section{CONCLUSION}

The concept of eco-city is changing the way cities are being built and resulting in new urban landscapes in Asia. It is applied in projects of different scales and in different urban setting such as greenfield projects or retrofit of existing cities. There is no one-size-fits-all formula. Differences in political system, economic conditions, and geographic characters necessitate different approaches to eco-city, as this comparative study reveals.
Japan and China represents two important models of implementing an eco-city. Eco-cities in Japan have a grassroots origin. Organized around national government's legislation and incentives, efforts within Japanese towns and cities are often driven by the local government, industry, and citizens, and involve support of the NGOs. As a result, Japanese ecocities have a clear focus on citizen involvement and initiatives, as well as strong awareness of recycling and other environmental practices. The "Three R's: Reduce, Reuse, Recycle" is the principal theme for most of Japan's eco-town projects. In contrast, eco-cities in China are characterized by a top-down process. The central government made the policies and created the standards of eco-city, and the local governments and state-owned corporations took charge in implementing the large-scale projects, expecting financial returns from the development of land. Participation takes place amongst 


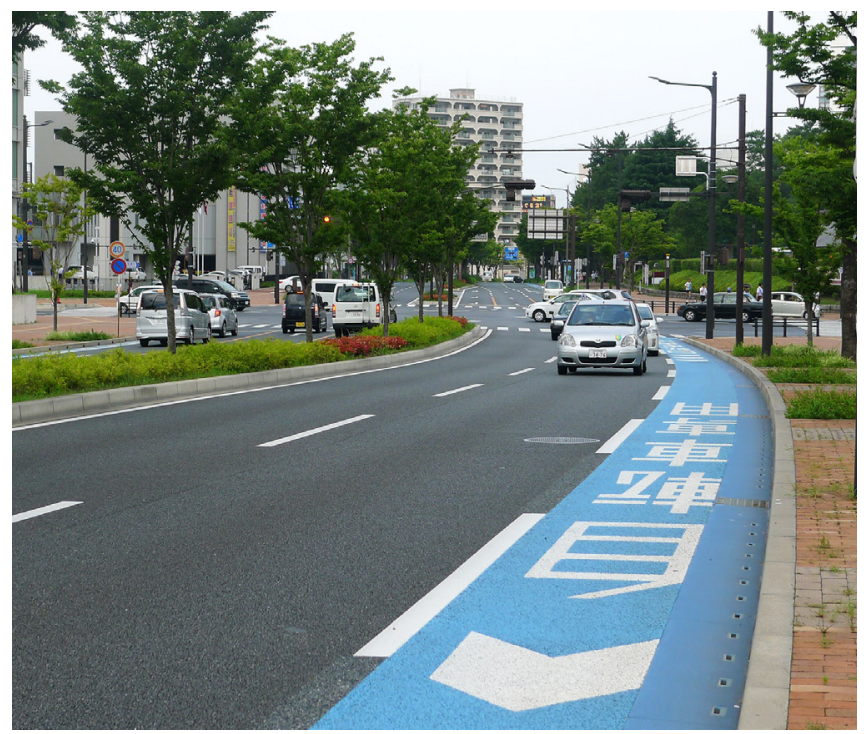

Fig 3: Street-scape in Kitakyushu

political and economic elites but does not involve communities. There seem to be an assumption that a sustainable lifestyle could be built into the city along with the introduction of recent technologies, which often turn out to be a naïve conception.

There are things that these two different models can learn from each other. Japanese cities could benefit from some experience of Chinese counterparts in stimulating economic vitality through the eco-city initiatives. Chinese governments, on the other hand, should investigate the means to bring the communities into this effort as a stakeholder, and enhancing the measures of sustainability with micro-scale interventions. As other scholars noted, Tianjin represents a unique position and possesses many advantages as a demo-project that other cities do not have. For example, government-sponsored lowcarbon industries, such as film animation and environmental technologies, are encouraged to relocate to Tianjin eco-city. Other eco-cities will not have the same level of investment or national government support, and their success will depend much more upon how the market perceive a potential environmental premium (Flynn, 2012). In addition, the urban sprawl and massive new town building that have been going on in China for decades will likely slow down in a few years as land resource becomes limited and cities becomes too large to be efficiently manage. Should this be the trend, Japan's approach to retrofit eco-development within the existing cities would represent more valuable experience for Chinese governments that continue to pursue forms of eco-city.

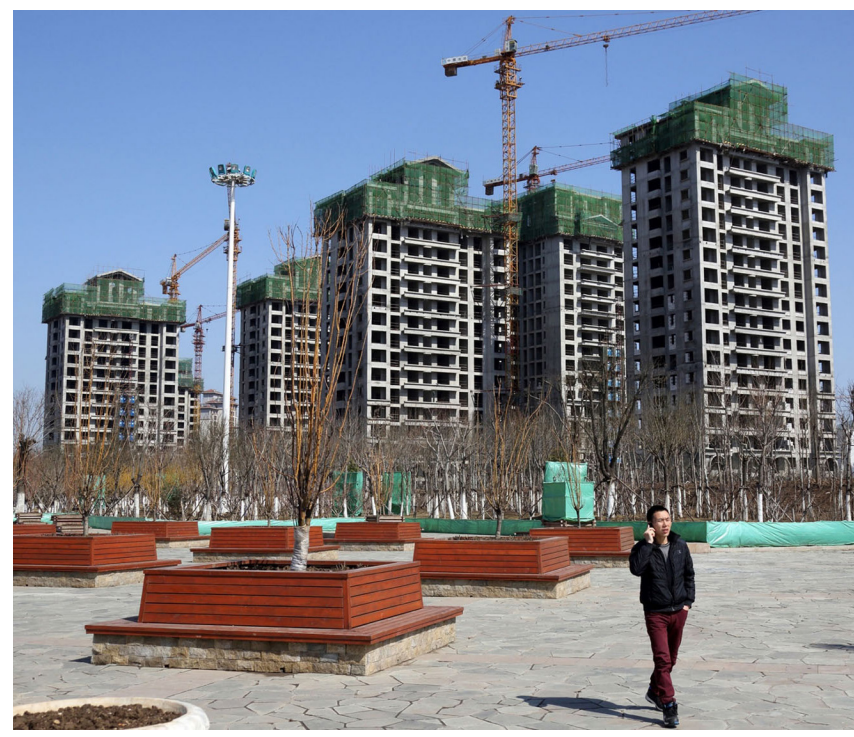

Fig 4: Urban Space in Tianjin Eco-citytur adipiscing.

\section{REFERENCES}

1 Baeumler, A. et al. (2012) Sustainable Low-Carbon City Development in China (The World Bank, Washington DC).

2 Berkel, Rene Van, et al. (2009) 'Industrial and Urban Symbiosis in Japan: Analysis of the Eco-Town Program 1997-2006', Journal of Environmental Management 90, 1544-1556.

3 China Urban Sciences Research Council (2011). Report of China's Low-carbon Eco-city Development (Beijing: China Architecture \& Building Press).

4 City of Kitakyushu (2012). Kitakyushu Eco-Future City Plan.

5 Flynn A. (2012) "Eco-Cities in China." Cardiff Case Studies: Geography.

6 Ghiglione, S. and Larbi M. (2015) "Eco-Cities in China: Ecological Urban Reality or Political Nightmare?" Journal of Management and Sustainability 5:1, 101-114.

7 Global Environment Centre Foundation (2005). Eco-Towns in Japan: Implications and Lessons for Developing Countries and Cities (GEC).

8 Joss, S. et al (2011) Eco-cities - A Global Survey 2011 (University of Westminster).

9 Li, Y. et al. (2012) Essential Building: The Emergence of Low Carbon Cities in PostIndustrial Urban China (Institute for Building Efficiency, Washington DC).

10 Low, M. (2013) “Eco-Cities in Japan: Past and Future," Journal of Urban Technology 20, 7-22.

11 Register, R. (1987) Ecocity Berkeley: Building Cities for a Healthy Future (North Atlantic Books, Berkeley).

12 Rowe, P. (2005) East Asian Modern: Shaping the Contemporary City (Reaktion Books, London).

13 State Council of Information of China (2005). "White Paper: China's Peaceful Deveopment Road."

14 Secretariat of the Kitakyushu Initiative Network (2010), Kitakyushu Initiative for a Clean Environment: Final Report (Institute for Global Environmental Strategies).

15 Sina News (2011). http://news.dichan.sina.com.cn/2011/02/14/275182.htm (Accessed Dec. 14, 2012)

16 Springer, C. (2012) "Directing the Demographic of the Sino-Singapore Tianjin Eco-City (SSTEC)." http://ecocitynotes.com (Accessed May 30, 2015).

17 Sustainable Cities International (2012) Indicators for Sustainability: How Cities are Monitoring and Evaluating Their Success.

18 Suzuki, H. et al. (2010) Eco2 Cities: Ecological Cities as Economic Cities (The World Bank, Washington DC).

19 Wong, T. and Yuen B. (2011) Eco-city Planning: Politics, Practice and Design (Springer, Dordrecht).

20 The World Bank (2009) Sino-Singapore Tianjin Eco-City: A Case Study of an Emerging Eco-City in China. 